BIOFARM

Jurnal Ilmiah Pertanian

ISSN Print: 0216-5430; ISSN Online: 2301-6442

Vol. 15, No. 2, Oktober 2019

\title{
Pengaruh Konsentrasi Zat Pengatur Tumbuh Air Kelapa Muda Terhadap Pertumbuhan Beberapa Varietas Jahe (Zingiber officinale rosc.)
}

\author{
The Influence Plant Growth Regulators Concentrate of Young Coconut Water \\ on Growth of Some Varieties of Ginger (Zingiber officinale rosc.)
}

\author{
Fatkhiyatul Rokhmah \\ Program Studi Agroteknologi, Fakultas Pertanian, Universitas Pekalongan \\ *Korespondensi Penulis: fatkhiyatulr17@gmail.com
}

\begin{abstract}
ABSTRAK
Jahe merupakan tanaman yang banyak digunakan sebagai bahan baku obat tradisional. Dalam budidaya jahe yang menjadi kendala adalah rimpang tidak tumbuh dengan cepat dan serempak. Penelitian ini bertujuan untuk mengetahui pengaruh konsentrasi air kelapa muda terhadap pertumbuhan beberapa varietas jahe dan interaksinya. Penelitian ini dilaksanakan di Kebun Benih Hortikultura Karanganyar Pekalongan. Rancangan yang digunakan adalah rancangan acak kelompok (RAK) dengan dua faktor dan tiga ulangan, Faktor pertama yaitu konsentrasi air kelapa muda $(0 \%, 25 \%, 50 \%, 75 \%)$, faktor kedua yaitu varietas jahe (jahe gajah, jahe emprit, jahe merah). Data dianalisis dengan uji F, jika berbeda nyata maka dilanjut dengan uji BNT. Variabel pengamatan meliputi kecepatan bertunas, tinggi tanaman, jumlah daun, jumlah tunas tiap rimpang, luas daun, diameter rimpang, bobot basah tanaman, berat rimpang per tanaman, volume rimpang, dan bobot kering tanaman. Hasil penelitian menunjukkan konsentrasi air kelapa muda berbeda sangat nyata terhadap variabel luas daun dan bobot basah tanaman. Perlakuan terbaik yaitu konsentrasi $50 \%$. Varietas jahe menunjukkan berbeda sangat nyata terhadap variabel kecepatan bertunas, tinggi tanaman, diameter rimpang dan bobot basah rimpang per tanaman. Perlakuan terbaik varietas jahe gajah. Interaksi antara konsentrasi air kelapa muda dan varietas jahe berbeda sangat nyata pada variabel luas daun dan berbeda nyata pada bobot basah rimpang per tanaman. Interaksi terbaik pada konsentrasi air kelapa muda 50\% dengan varietas jahe gajah.
\end{abstract}

Kata kunci : rimpang, air kelapa muda, jahe

\section{ABSTRACT}

Ginger is a plant that widely used as traditional medicines. The problem in cultivating ginger was the rhizomes could not grow quickly and uniformed. This research was aimed to determine the effect of young coconut water concentrate on growth of some varieties of ginger and theirs interaction. This research had been conducted in Garden of Horticultural Seeds, Karanganyar Pekalongan since Maret to Juni 2018. Experimental design was used Randomized Block Design (RBD) with 2 factors and 3 replications. The first factors was the concentrate of coconut water $(0 \%$, $25 \%, 50 \%, 75 \%)$, second factors was the some varieties of ginger (Gajah ginger, Emprit ginger, Red ginger). Data analysis using $F$ test, if there very significant analysis continued with BNT test. Observation variables included speed sprout, plant height, leaf number, number of tillers, leaf area, rhizome diameter, wet weight of plant, wet weight of rhizome, volume of rhizome, and dry weight of plant. The result showed that coconut water concentrate is very significant on variable leaf area and wet weight of plant. Best treatment is in 50\% coconut water concentrate. Ginger varieties was very significant on variable speed sprout, plant hight, rhizome diameter, and wet weight rhizome. Best treatment is in Gajah ginger. There was interaction between kinds of ginger with coconut water concentrate on variable leaf area very significant and significant on weight of rhizome. The best interaction is in $50 \%$ young coconut water concentrate and varietas Gajah ginger.

Keywords : rhizome, young coconut water, ginger.

\section{PENDAHULUAN}

Jahe (Zingiber officinale Rosc.) merupakan salah satu jenis tanaman obat berupa tumbuhan rumpun berbatang semu yang mempunyai banyak kegunaan baik sebagai rempah, bumbu penyedap, bahan baku industri obat tradisional, fitofarmaka, makanan dan minuman kesehatan, serta produk kosmetik dan perawatan tubuh (Rostiana dkk., 2009).
Di Indonesia dikenal tiga tipe utama jahe berdasarkan bentuk, warna, dan aroma rimpang, yaitu jahe gajah atau badak atau putih besar, jahe merah atau jahe sunti dan jahe putih kecil atau jahe emprit (Rostiana dkk., 1991). Jahe putih besar (gajah/badak), rasanya tidak terlalu pedas, umumnya digunakan sebagai bahan makanan seperti manisan, dan juga untuk minuman segar. Jahe putih kecil (jahe emprit) mempunyai 
rasa lebih pedas dari jahe putih besar, umumnya digunakan untuk bumbu masak, sumber minyak atsiri dan pembuatan oleoresin serta bubuknya banyak dimanfaatkan dalam ramuan obat tradisional (jamu). Sedangkan jahe merah mempunyai kandungan minyak atsiri yang tinggi (Yuliani dkk., 1991).

Menurut BPS (2009) produktivitas jahe secara nasional dalam kurun waktu 20102012 menunjukkan bahwa pada tahun 2010 produktivitas jahe sebesar 1,68 ton/ha, pada tahun 2011 produktivitas jahe mengalami penurunan sebesar 1,62 ton/ha, dan pada 2012 produktivitas jahe meningkat menjadi 1,92 ton/ha. Produktivitas jahe yang tidak stabil tersebut selain disebabkan oleh cara budidaya yang belum optimal, juga disebabkan oleh penggunaan bahan tanaman yang kurang bermutu.

Salah satu usaha dalam mem-peroleh produk tanaman jahe secara kontinyu dalam waktu singkat pada umumnya diperbanyak secara vegetatif, yaitu berupa tunas muda (anakan) dan dengan potongan atau stek rimpang. Usaha yang dapat dilakukan agar rimpang cepat tumbuh dan pertumbuhannya seragam diantaranya adalah dengan penggunaan zat pengatur tumbuh.

Perendaman rimpang dengan senyawa kimia seperti auksin sintetik sudah lazim dilakukan untuk memacu perakaran pada berbagai jenis tanaman (Hartman dan Kester, 1978). Zat pengatur tumbuh sintetis banyak beredar di pasaran sehingga mudah didapatkan, namun di sisi lain harganya relatif lebih mahal dan penggunaannyapun memerlukan ketelitian dan kecermatan. Sehubungan dengan hal tersebut maka perlu dicari alternatif penggunaan zat pengatur tumbuh yang murah, mudah diperoleh serta efektif misalnya zat pengatur tumbuh alami.

Salah satu bahan yang dapat digunakan sebagai zat pengatur tumbuh adalah air kelapa. Menurut Siahaan (2004), penggunaan ZPT oleh petani belum memasyarakat, karena air kelapa muda dapat dimanfaatkan sebagai ZPT alternatif dengan harga terjangkau, mudah didapat serta aman bagi kesehatan namun masih tetap efektif untuk digunakan. Air kelapa muda merupakan suatu bahan alami yang di dalamnya terkandung hormon seperti sitokinin 5,8 $\mathrm{mg} / \mathrm{l}$ yang dapat merangsang pertumbuhan tunas dan mengaktifkan kegiatan jaringan atau sel hidup, hormon auksin 0,07 mg/L dan sedikit giberelin serta senyawa lain yang dapat menstimulasi perkecambahan dan pertumbuhan (Bey dkk., 2006).

Salisbury dan Ross (1995), menyatakan ZPT merupakan suatu zat pendorong pertumbuhan apabila diberikan dalam konsentrasi yang tepat. Sebaliknya bila diberikan dalam konsentrasi yang tinggi dari yang dibutuhkan tanaman maka akan menghambat dan menyebabkan kurang aktifnya proses metabolisme tanaman.

Upaya lain untuk meningkatkan produksi jahe adalah dengan menggunakan varietas unggul. Penggunaan varietas unggul merupakan teknologi yang dapat diandalkan, umumnya varietas unggul memiliki berbagai sifat yang diinginkan, yang menonjol dalam hal potensi yang tinggi, tahan terhadap organisme pengganggu tertentu dan memiliki keunggulan pada ekologis tertentu serta mempunyai sifat-sifat agronomis lainnya (Erwin, 2012). Varietas yang digunakan dalam penelitian ini adalah Jahe Putih Besar (Jahe Gajah), Jahe Putih kecil (Jahe Emprit) dan Jahe Merah.

Berdasarkan uraian diatas, penelitian ini dilakukan dengan tujuan mengetahui konsentrasi air kelapa muda yang optimum untuk pertumbuhan Jahe, mengetahui varietas jahe yang pertumbuhannya paling baik dan mengetahui interaksi antara konsentrasi air kelapa muda dan varietas jahe terhadap peningkatan pertumbuhan jahe.

\section{METODE PENELITIAN}

Penelitian telah dilaksanakan di Kebun Benih Hortikultura Karanganyar Kabupaten Pekalongan pada ketinggian tempat \pm 80 meter di atas permukaan laut (mdpl). Penelitian dilaksanakan selama 4 bulan, yaitu mulai bulan Maret sampai dengan Juni 2018. Penelitian ini merupakan percobaan faktorial dengan 2 faktor 3 ulangan. Faktor yang dicoba adalah konsentrasi air kelapa muda $(\mathrm{K})$ dan varietas jahe (V). Konsentrasi air kelapa muda terdiri dari $\mathrm{K} 0$ : 0\%, K1: 25\%, K2 : 50\%, K3 : 75\%. Varietas jahe terdiri dari V1: jahe gajah, V2 : jahe emprit V3 : Jahe merah. Sehingga diperoleh 12 kombinasi perlakuan, masing-masing kombinasi perlakuan diulang tiga kali yang seluruhnya ada 36 satuan percobaan. Satuan percobaan terdiri dari lima tanaman sampel sehingga seluruhnya ada $36 \times 5=$ 180 tanaman sampel. 
Variabel yang diamati meliputi : Kecepatan bertunas (hari), tinggi tanaman (cm), jumlah daun (helai), jumlah tunas tiap rimpang (buah), luas daun (cm2), diameter rimpang $(\mathrm{mm})$, bobot basah tanaman (gram), berat rimpang per tanaman (gram), volume rimpang $(\mathrm{ml})$, bobot kering tanaman (gram Data dianalisis dengan analisis sidik ragam berdasarkan uji $\mathrm{F} 5 \%$ dan $1 \%$. Jikaberpengaruh nyata dilanjutkan dengan uji
BNT 5\%. Konsentrasi air kelapa muda dilanjutkan dengan uji regresi sedangkan varietas jahe dilanjutkan dengan kontras orthogonal.

\section{HASIL DAN PEMBAHASAN \\ Pengaruh Konsentrasi Air Kelapa Muda}

Hasil penelitian menunjukkan bahwa perlakuan konsentrasi air kelapa muda berbeda sangat nyata pada variabel luas

Tabel 1. Angka rata-rata dan Analisis Statistik Data Penelitian Pengaruh Kosentrasi Air Kelapa Muda dan Varietas Jahe.

\begin{tabular}{|c|c|c|c|c|c|}
\hline Perlakuan & $\begin{array}{c}\text { Kecepatan } \\
\text { Bertunas } \\
\text { (hari) }\end{array}$ & $\begin{array}{l}\text { Tinggi } \\
\text { Tanaman } \\
\text { (cm) }\end{array}$ & $\begin{array}{c}\text { Jumlah } \\
\text { Daun (helai) }\end{array}$ & $\begin{array}{c}\text { Jumlah } \\
\text { Tunas Tiap } \\
\text { Rimpang } \\
\text { (buah) }\end{array}$ & $\begin{array}{l}\text { Luas } \\
\text { Daun } \\
\text { (cm2) }\end{array}$ \\
\hline \multicolumn{6}{|l|}{ Konsentrasi Air Kelapa Muda } \\
\hline $\mathrm{K} 0=0 \%$ & 23,67 & 43,23 & 31,24 & 7,48 & $25,15 \mathrm{c}$ \\
\hline $\mathrm{K} 1=25 \%$ & 23,50 & 42,53 & 29,98 & 7,19 & $19,11 b$ \\
\hline $\mathrm{K} 2=50 \%$ & 26,00 & 36,04 & 24,96 & 6,70 & $16,78 \mathrm{a}$ \\
\hline$K 3=75 \%$ & 24,67 & 41,94 & 26,29 & 6,00 & $19,69 \mathrm{~b}$ \\
\hline \multicolumn{6}{|l|}{ Varietas Jahe } \\
\hline V1 = Jahe Gajah & $21,1 \mathrm{a}$ & $35,1 \mathrm{a}$ & 25,3 & 6,7 & 20,1 \\
\hline V2 = Jahe Emprit & $27,08 b$ & $38,08 a$ & 27,27 & 7,14 & 18,80 \\
\hline V3 = Jahe Merah & $25,3 a$ & $49,7 \mathrm{~b}$ & 31,8 & 6,7 & 21,6 \\
\hline
\end{tabular}

Keterangan : Angka yang diikuti huruf yang sama pada kolom dan baris menunjukkan tidak berbeda nyata menurut uji BNT taraf $5 \%$

daun dan bobot basah tanaman. Hasil tertinggi dari luas daun dicapai pada konsentrasi 0\% (KO). Daun terluas dicapai pada rimpang jahe yang direndam dengan air biasa (kontrol), hal ini disebabkan air sudah dapat melakukan imbibisi ke rimpang jahe, imbibisi terjadi karena potensial air di dalam benih lebih rendah dari sekitarnya, sehingga air akan bergerak masuk ke dalam benih (Beneach dan Sanchez, 2004). Hal ini disebabkan fitohormon yang ada pada rimpang cukup untuk memenuhi pertumbuhan sehingga air yang masuk sudah dapat memacu pembentukan fitohormon yang ada dalam tanaman. Fitohormon dihasilkan oleh tanaman pada saat awal pertumbuhan dimana jumlah hormon yang paling banyak diproduksi adalah auksin.

Tabel 2. Angka rata-rata dan Analisis Statistik Data Penelitian Pengaruh Kosentrasi Air Kelapa Muda dan Varietas Jahe.

\begin{tabular}{|c|c|c|c|c|c|}
\hline Perlakuan & $\begin{array}{c}\text { Diameter } \\
\text { Rimpang } \\
\quad(\mathrm{mm})\end{array}$ & $\begin{array}{l}\text { Bobot Basah } \\
\text { Tanaman (g) }\end{array}$ & $\begin{array}{l}\text { Bobot Basah } \\
\text { Rimpang Per } \\
\text { Tanaman (g) }\end{array}$ & $\begin{array}{c}\text { Volume } \\
\text { rimpang (ml) }\end{array}$ & $\begin{array}{c}\text { Bobot } \\
\text { Kering } \\
\text { Tanaman } \\
\text { (g) }\end{array}$ \\
\hline \multicolumn{6}{|c|}{$\begin{array}{l}\text { Konsentrasi Air Kelapa } \\
\text { Muda }\end{array}$} \\
\hline $\mathrm{K} 0=0 \%$ & 1,36 & $48,74 a$ & 16,14 & 10,78 & 7,83 \\
\hline$K 1=25 \%$ & 1,33 & $49,69 a$ & 15,28 & 13,67 & 7,57 \\
\hline$K 2=50 \%$ & 1,33 & $64,64 \mathrm{c}$ & 16,46 & 13,52 & 7,22 \\
\hline $\mathrm{K} 3=75 \%$ & 1,31 & $63,91 \mathrm{~b}$ & 13,54 & 11,85 & 8,80 \\
\hline \multicolumn{6}{|l|}{ Varietas Jahe } \\
\hline V1 = Jahe Gajah & $1,4 a$ & 57,4 & $17,7 b$ & 12,8 & 7,0 \\
\hline V2 = Jahe Emprit & $1,15 a$ & 53,92 & $11,01 \mathrm{a}$ & 9,86 & 7,71 \\
\hline V3 = Jahe Merah & $1,5 b$ & 58,9 & $17,3 a$ & 14,7 & 9,0 \\
\hline
\end{tabular}


Hasil penelitian menunjukkan bahwa perlakuan konsentrasi air kelapa muda Berbeda sangat nyata terhadap variabel bobot basah tanaman. Konsentrasi terbaik dicapai pada pemberian $50 \%$ (K2) yaitu 64,64 gram. Hal ini disebabkan kandungan auksin yang terdapat dalam air kelapa muda dengan konsentrasi $50 \%$ sudah mencukupi untuk mempengaruhi pemanjangan sel pada tanaman. Cara kerja auksin adalah mempengaruhi pengendoran dinding sel. Sel tumbuhan kemudian memanjang akibat air yang masuk secara osmosis, selain itu memacu pemanjangan sel yang menyebabkan pemanjangan batang dan akar sehingga menyebabkan meningkatnya bobot basah tanaman (Rusmin, 2011).

\section{Pengaruh Varietas Jahe}

Hasil Penelitian menunjukkan bahwa varietas jahe berbeda sangat nyata terhadap kecepatan bertunas. Jahe gajah memberikan respon tercepat terhadap kecepatan bertunas yaitu rata-rata 21,1 hari, kemudian disusul jahe merah 25,3 hari, sedangkan respon paling lambat pada varietas jahe emprit 27,08 hari. Perbedaan sangat nyata ini karena secara genetik rimpang jahe gajah mempunyai rimpang yang lebih gemuk, sehingga mengandung banyak nutrisi atau cadangan makanan, hal ini berpengaruh terhadap meningkatnya proses metabolisme.

Berat rimpang jahe gajah 300-2000 g/rumpun, jahe merah $432,47 \pm 108,90$ dan jahe emprit 375,07 $\pm 165,56 \mathrm{~g} /$ rumpun. Menurut Kramer dan Kozlowski (1979), untuk pertumbuhan tunas diperlukan bahan pembangun lain, karbohidrat yang terdapat pada stek itu sendiri, oleh karena itu apabila digunakan untuk bibit, kebutuhan makanan untuk pertumbuhan tanaman dapat tercukupi, akibatnya pertunasan, pertumbuhan dan perkembangan tanaman akan lebih cepat.

Hasil penelitian menunjukkan bahwa varietas jahe berbeda sangat nyata terhadap tinggi tanaman. Tinggi tanaman tertinggi dicapai pada varietas jahe merah (V3) 49,7 $\mathrm{cm}$, kemudian disusul jahe emprit (V2) 38,08

Tabel 3. Angka rata-rata Interaksi Pengaruh Kosentrasi Air Kelapa Muda dan Varietas Jahe

\begin{tabular}{lcc} 
Perlakuan & Luas Daun $(\mathrm{cm})$ & $\begin{array}{c}\text { Bobot Basah Rimpang Per } \\
\text { Tanaman }(\mathrm{g})\end{array}$ \\
\hline K0V1 & $24,84 \mathrm{~d}$ & $19,85 \mathrm{e}$ \\
K0V2 & $25,64 \mathrm{~d}$ & $12,39 \mathrm{~b}$ \\
K0V3 & $24,97 \mathrm{~d}$ & $16,18 \mathrm{c}$ \\
K1V1 & $19,60 \mathrm{c}$ & $17,95 \mathrm{~d}$ \\
K1V2 & $20,14 \mathrm{c}$ & $9,57 \mathrm{a}$ \\
K1V3 & $17,59 \mathrm{~b}$ & $18,30 \mathrm{~d}$ \\
K2V1 & $20,54 \mathrm{c}$ & $21,28 \mathrm{f}$ \\
K2V2 & $14,10 \mathrm{a}$ & $12,31 \mathrm{~b}$ \\
K2V3 & $15,71 \mathrm{a}$ & $15,80 \mathrm{c}$ \\
K3V1 & $15,44 \mathrm{a}$ & $11,73 \mathrm{~b}$ \\
K3V2 & $15,31 \mathrm{a}$ & $9,77 \mathrm{a}$ \\
K3V3 & $28,33 \mathrm{e}$ & $19,11 \mathrm{~d}$ \\
\hline
\end{tabular}

Keterangan : Angka yang diikuti huruf yang sama pada kolom dan baris menunjukkan tidak berbeda nyata menurut uji BNT taraf $5 \%$

$\mathrm{cm}$, sedangkan tinggi tanaman terendah pada varietas jahe gajah (V1) sebesar 35,1 $\mathrm{cm}$. perbedaan tinggi ini karena ketiga jenis Menurut sukarman dkk (2008), faktor lingkungan utama yang dapat mempengaruhi dimulai dari riwayat lahan, iklim (cahaya, suhu, curah hujan dan angin), kesuburan dan kelembaban tanah, serta faktor biologis (hama, penyakit dan gulma). Faktor lain yang mempengaruhi hasil adalah varietas, rotasi tanaman, ukuran dan umur benih (Mugnisyah dan Setiawan, 1990). Jahe merah memiliki 
tinggi tanaman tertinggi, tinggi tanaman yang baik menunjukkan tanaman mempunyai hasil asimilat yang cukup tersimpan dalam batang, yang kemudian akan digunakan untuk pertumbuhan selanjutnya.

Hasil penelitian menunjukkan bahwa perlakuan pengaruh varietas jahe berpengaruh sangat nyata terhadap diameter rimpang. Diameter rimpang terlebar dicapai pada V3 (jahe merah) yaitu $1,5 \mathrm{~mm}$. Diameter rimpang yang lebar diartikan bahwa volume rimpang dalam menyimpan hasil asimilat dari fotosintesis yang tinggi, didukung dengan banyaknya jumlah daun pada varietas jahe merah sehingga hasil asimilat yang diterima rimpang lebih banyak dan diameter rimpang yang luas mampu menyediakan cadangan makanan seperti protein, karbohidrat, dan pati untuk pertumbuhan tanaman. Apabila bahan yang digunakan untuk mensuplai pembentukan rimpang tersedia dalam jumlah banyak, maka rimpang yang terbentuk lebih besar dan mempengaruhi diameter rimpang. Hasil penelitian menunjukkan bahwa perlakuan varietas jahe berbeda sangat nyata terhadap variabel bobot basah rimpang per tanaman. Varietas dengan bobot rimpang terbaik adalah varietas jahe gajah (V1) yaitu 17,7 gram, diikuti varietas jahe merah 17,3 gram dan yang memiliki bobot terendah ialah jahe emprit 11,01 gram. Jahe gajah merupakan varietas terbaik dalam menyimpan cadangan makanan yang berupa rimpang, lebih efektif dibanding varietas lainnya. Secara genetik rimpang jahe gajah memiliki bobot 300-2000 g/rumpun, jahe merah $432,47 \pm 108,90$ g/rumpun dan jahe emprit 375,07 $\pm 165,56$ g/rumpun.

\section{Interaksi antara Konsentrasi Air Kelapa Muda dan Varietas Jahe}

Hasil Penelitian menunjukan bahwa interaksi antara konsentrasi air kelapa muda dengan varietas jahe tidak berbeda nyata terhadap semua variabel kecuali variabel luas daun dan bobot basah rimpang per tanaman. Interaksi terbaik diperoleh pada konsentrasi air kelapa muda 50\% dengan varietas jahe gajah (K2V1). Interaksi ini terjadi karena adanya saling mendukung antara konsentrasi air kelapa muda $50 \%$ dan varietas jahe gajah yang lebih responsife terhadap pertumbuhan tanaman yang ditunjukkan dengan luas daun dan bobot basah rimpang per tanaman. Konsentrasi air kelapa muda $50 \%$ menyediakan zat pengatur tumbuh yang cukup untuk pertumbuhan tanaman.

Menurut Djamhari (2010), zat pengatur tumbuh yang diaplikasikan pada tanaman berfungsi untuk memacu pembentukan fitohormon. Hormon dapat mendorong suatu aktifitas biokimia, fitohormon yang bekerja aktif dalam jumlah sedikit ditransformasikan ke seluruh bagian tanaman sehingga dapat mempengaruhi pertumbuhan atau prosesproses fisiologi tanaman. Perendaman rimpang didalam air kelapa muda bertujuan untuk menyuplai tambahan senyawa alami berupa hormon eksogen yang nantinya akan bekerja membantu hormon endogen dalam metabolisme di dalam rimpang jahe. Varietas jahe gajah lebih responsif terhadap konsentrasi air kelapa muda, sehingga keduanya saling bersinergi untuk membentuk luas daun dan bobot basah rimpang per tanaman, hal ini sependapat dengan Prihmantoro (2007), bahwa apabila unsur hara yang diperlukan oleh tanaman sudah terpenuhi, maka proses fisiologis tanaman akan berjalan dengan baik dan akan memacu pertumbuhan dan perkembangan tanaman.

\section{SIMPULAN}

Berdasarkan hasil penelitian dan pembahasan dapat ditarik beberapa simpulan sebagai berikut :

1. Perlakuan konsentrasi air kelapa muda tidak berbeda nyata terhadap semua variabel kecuali pada variabel luas daun dan bobot basah tanaman berbeda sangat nyata. Hasil yang terbaik yaitu konsentrasi air kelapa muda $50 \%$ (K2).

2. Perlakuan varietas jahe berpengaruh sangat nyata terhadap kecepatan bertunas, tinggi tanaman, bobot basah rimpang per tanaman, dan diameter rimpang, sedangkan variabel lainnya tidak berbeda nyata. Varietas jahe gajah (V1) memberikan hasil terbaik. 
3. Interaksi antara konsentrasi air kelapa muda dengan varietas berpengaruh sangat nyata terhadap variabel luas daun dan berpengaruh nyata terhadap bobot basah rimpang per tanaman. Pertumbuhan terbaik dicapai pada interaksi konsentrasi air kelapa muda $50 \%$ dan varietas jahe gajah (K2V1).

\section{DAFATAR PUSTAKA}

Academic Press Inch. London Mugnisyah, W. Q. dan A. Setiawan.1990. Pengantar Produksi Benih. Rajawali Press, Jakarta.

Beneach AR, Sanchez RA. 2004. Handbook of Seed Physiology: Aplications to Agriculture. New York, London: Haworth Press.

BPS. 2009. Produktivitas Tanaman ObatObatan di Indonesia. http://bps.go.id. (on-line). Diakses tanggal 15 November 2017

Djamhari, S. 2010. Memecah dormansi rimpang temulawak menggunakan larutan atonik dan stimulasi perakaran dengan aplikasi auksin. Jurnal Sains danTeknologi Indonesia.

Hartman, A.T dan Dt. Kester. 1978. Plant Propagation, Principle and Practice. Prentice Hall Inc. New Jersey. 662P.http://dishutbunkerinci.wordpr ess.com/2012/07/prose pelepasanvarietas-unggul-pd.html? $\mathrm{m}=1$. (online). Diakses 12 Januari 2018

Inc Bey, Y, Syafii, W. dan Sutrisna. 2006. Pengaruh Pemberian Giberelin (GA3) dan Air Kelapa Terhadap Perkecambahan Biji Anggrek Bulan (Phalaenopsis ambilis BL) secara in vitro. Jurnal. Universitas Riau, Pekanbaru.
Kramer, P.J. dan Kozlowski, T.T. 1979. Physiology of Woody Plant.

ostiana, O., A. Abdullah, Taryono dan, E. A. Hadad. 1991. Jenis - Jenis Tanaman Jahe. Edisi Khusus Littro VII (1) : 7-10.

Rostiana, O., N. Bermawie, dan M. Rahardjo. 2009. Standar Prosedur Operasional Budidaya Jahe. dipublikasikan di http:// balittro. litbang. pertanian.go.id > publikasi (on-line). Diakses pada tanggal 16 Januari 2017

Rusmin, D. 2011. Pengaruh Pemberian GA3 pada Berbagai Konsentrasi dan Lama Imbibisi terhadap Peningkatan Viabilitas Benih Purwoceng. Jurnal Littri Vol:17 No:3

Salisbury,B.F. Dan Ross,W.C.1995. Fisiologi Tumbuhan. ITB. Bandung.

Siahaan, E. 2004. Pengaruh Kosentrasi Air Kelapa Muda Terhadap Pertumbuhan Produksi Cabai Merah (Capsicum annum L.). Skripsi. Fakultas Pertanian. Universitas Riau. (Tidak Dipublikasikan).

Sukarman. 2008. Pengaruh Lokasi ProduKsi dan Lama Penyimpanan Terhadap Mutu Benih Jahe (Zingiber Officinale L.). Jurnal Littri 14(3), September 2008. HIm.119-124

Yuliani,S., Hernani dan Anggraeni. 1991. Aspek Pasca Panen Jahe. Edisi Khusus Littro VII (1) : 30-37. 